\title{
DO FATO À REPORTAGEM: O AMBIENTE DA TRADUÇÃO JORNALÍSTICA
}

\section{Meta Elisabeth Zipser ${ }^{1}$}

\author{
Silvana Ayub Polchlopek ${ }^{2}$
}

\begin{abstract}
Resumo: As últimas três décadas têm firmado os estudos da tradução como uma área independente no campo de pesquisas acadêmicas, possibilitando a integração de áreas distintas como a tradução e o jornalismo. É nessa arena de discussões que esse artigo se insere, colocando o jornalismo como um organizador de perfis culturais na sociedade e a tradução como a representação cultural de fatos noticiosos, especialmente quando as notícias transitam em ambiente internacional. Essa mobilidade resulta em deslocamentos de enfoque, configurando o jornalismo como a tradução do fato noticioso, ou seja, sua representação cultural (ZIPSER, 2002). Ancorado nas teorias de Christiane Nord (1991 tradução) e Frank Esser (1998 - jornalismo), o artigo apresenta a interface Tradução-Jornalismo, consolidando o caráter interdisciplinar dos estudos tradutórios.
\end{abstract}

Palavras-Chave: Tradução, jornalismo, funcionalismo, cultura.

\begin{abstract}
Within the last three decades, translation studies has established itself as an independent field in the academic area, enabling the integration of distinctive areas such as translation and journalism, which is the focus of this paper. Journalism is pointed out as a cultural map, within the social contexts in which it is inserted in, while translation is understood as the cultural representation of news-facts, especially in which international contexts are concerned. Such mobility results in shifts of focus, which enables one to view Journalism as the translation of a fact, that is, its cultural representation (ZIPSER, 2002). Based on the theories of Christiane Nord (1991-Translation) and Frank Esser (1998 - Journalism), this paper aims to present the Translation-Journalism interface which configures the interdisciplinary character of Translation Studies.
\end{abstract}

Keywords: Translation, journalism, functionalism, culture.

Por muito tempo a tradução ficou relegada ao papel de coadjuvante enquanto instrumento para aprendizagem de idiomas, ora vista com bons olhos, ora desprezada por educadores. Hoje, no entanto, o que antes era apenas um instrumento de ensino vem se desenvolvendo como um campo bastante produtivo e significativo no âmbito das pesquisas acadêmicas. Os resultados vão desde discussões acerca da teoria e da prática efetiva, novas

\footnotetext{
${ }^{1}$ Doutora em Letras Alemão-Português pela Universidade de São Paulo. É professora associada da Universidade Federal de Santa Catarina (UFSC), atuando no Programa de Pós-graduação em Estudos da Tradução.

${ }^{2}$ Mestre em Estudos da Tradução pela Universidade Federal de Santa Catarina (UFSC).
} 
metodologias de pesquisa até parcerias com áreas afins possibilitando a criação de interfaces de investigação como a tradução e a cognição, publicidade, antropologia, filosofia, psicanálise e o jornalismo, nosso centro de atenção.

A parceria entre tradução e jornalismo resultou na criação da interface traduçãojornalismo (ZIPSER, 2002) abrindo novos caminhos de estudo e reforçando a característica interdisciplinar da área. A conjugação dos estudos da tradução com outras áreas da comunicação é defendida por Mona Baker (1996 in MARTINS, 1999, p. 15) como meio de ampliar as discussões sobre a abrangência que o fenômeno da tradução impõe cada vez mais. Tal postura demonstra a complexidade e a consistência desse ambiente de pesquisa, abrindo novas possibilidades de se pensar o ato tradutório.

\section{A tradução no espaço da imprensa}

Em meio jornalístico, a tradução é normalmente relegada ao que se chama de tradução consensual, ou seja, a tradução literal segundo o senso comum, cuja prática é sempre muito presente na cultura das redações. Não é raro um jornalista assumir a posição de tradutor, considerando-se que uma eventual contratação de profissionais tradutores geralmente onera o custo final do trabalho e demanda treinamento destes na prática de redação razão pela qual, somente grandes veículos da imprensa tendem a contratar tradutores profissionais. Na grande maioria das vezes, é o próprio jornalista quem exerce essa "função", bastando para isso conhecer o idioma estrangeiro em questão e ter realizado alguns trabalhos com sucesso, isto é, ter traduzido corretamente, sem "alterar" ou "distorcer" a informação. Explica-se, desse modo, a tradução consensual, aquela "fiel à letra", como transcodificação isenta e que se propõe objetiva, imparcial e neutra no relato do fato jornalístico, como convém aos princípios éticos que regem a imprensa.

Esses princípios, no entanto, inexistem nas instâncias da prática em si. Os veículos da imprensa normalmente tem pautas programadas e que obedecem ao que se chama de "valoresnotícia" ou critérios de noticiabilidade, isto é, atributos do fato noticioso que o tornam passível de ser transformado em notícia, afinal a notícia é também destinada a venda e ao consumo (MEDINA, 1988). Segundo Traquina (2001), três pontos devem ser considerados: i) a origem dos fatos, cujas características traduzem se pode ou não "virar" notícia; ii) o tratamento dado ao fato, isto é, localização na página, qualidade de fotografia, a apuração do conteúdo e, iii) a visão dos fatos, sua angulação e foco para a construção do discurso jornalístico. Alguns dos critérios de noticiabilidade são também apresentados por Franzon (2004), a saber: 
proeminência; proximidade (geográfica e cultural); impacto (número de pessoas envolvidas, afetadas); surpresa; raridade; drama/tragédia (catástrofes, acidentes, risco de morte, crime, violência, emoção, suspense; conflito (guerra).

Convem lembrar, no entanto, que os fatos não são veiculados sem antes serem revisados por editores-chefes ou chefes de redação, o que pode vir a alterar a sua ordem estrutural, conteudística ou mesmo a perspectiva de abordagem do fato. O questionamento decorrente dessa realidade diz respeito à razão da ocorrência destas alterações (previstas) nos textos e se existe(m) algum(ns) fator(es) que as determinem.

Um caminho para essa resposta é pensar que a imprensa é uma instituição social que vive, primordialmente, de notícias geradas dentro e fora do seu universo histórico-social, não estando, portanto, isenta de receber influências externas, especialmente as culturais. Lembramos ainda que a imprensa não escreve para si, visto que no outro vértice desse relacionamento está o público-leitor, o qual atribui ao jornalismo a característica de "olhos e ouvidos da nação" e espera ser (bem) informado, com a devida isenção, mesmo indiretamente atuantes através dos critérios de noticiabilidade.

Sendo assim, a reportagem originalmente escrita pelo jornalista pode sofrer alterações de maneira a seguir angulações e enfoques determinados por conta até mesmo das características do veículo midiático, especialmente quando se trata de um fato de repercussão internacional. Nesse caso, a própria escolha do fato a ser noticiado, considerando-se os valoresnotícia do contexto cultural de chegada, bem como a forma como será abordado, refletem os padrões histórico-sociais vigentes de informação.

Presumimos, portanto, que exista um filtro entre a notícia e o seu relato na imprensa (ZIPSER, 2002). Nesse sentido, a leitura que recebemos dos acontecimentos é, a exemplo das diversas traduções de um mesmo texto, apenas uma das muitas que um mesmo fato noticioso pode receber. Por essa razão, privilegia-se a pesquisa comparativa em contexto internacional na medida em que, através dela, é possível apreender diferentes perspectivas de enfoque conferidas a um mesmo fato gerador, bem como a situação histórico-social em que a matéria jornalística foi produzida, o modo como o texto é organizado para chegar até o leitordestinatário, além do perfil jornalístico de cada país (ESSER, 1998). Não há mais sentido, portanto, para a "teoria do espelho"(TRAQUINA, 2001, p. 65), segundo a qual as notícias são como são porque a realidade as determina, símbolo de um jornalismo antes desinteressado. Para Adelmo Genro Filho (1987), a imprensa pode distorcer, reordenar e trocar de lugar esse espelho dependendo da importância dos detalhes e, porque não dizer, de determinadas condições sócio- 
histórico-culturais como, por exemplo, a representatividade, proximidade ou distanciamento geográfico e cultural desse acontecimento, dentre os contextos envolvidos.

Podemos dizer, assim, que o jornalismo resulta em um mapa cultural da sociedade na qual está inserido, visto que denota a tentativa (consciente ou não) por parte do jornalista de aproximar o fato noticioso do leitor que está cultural e/ou geograficamente distante do fato. Através dessa articulação com o social, o jornalismo assume a função de informar e formar opiniões, pautando o que o leitor fala, discute e comenta e atuando como organizador e tradutor de perfis sociais. Conseqüentemente, nos permitimos discordar de Traquina (2001) afirmando que a imprensa sabe como ninguém dizer ao público sobre o que pensar e como pensar, em razão de que o leitor final não só compartilha dos mesmos traços culturais do jornalista, do veículo como um todo, mas também compra a revista, o jornal ou lê o site diariamente. Nesse sentido, os textos jornalísticos (TJ) abrem espaço para a compreensão ou afastamento do Outro ao empregar marcas culturais do contexto do leitor-destinatário para o relato do fato noticioso. Ressalta-se que essas marcas estão sempre presentes, ainda que nem sempre facilmente visíveis, construindo um espaço de identificação do leitor com o texto e traduzindo diferentes perfis sociais.

De forma a sustentar tais afirmações e explicitar como atua a proposta de integrar a tradução e o jornalismo, fazemos uso de uma triangulação de teorias que contempla, num primeiro momento, duas perspectivas teóricas distintas, porem comparáveis: a tradução através de Christiane Nord (1991) e o jornalismo com Frank Esser (1998). Ambos reúnem a combinação da prática acadêmica com a reflexão teórica, sistematizando fatores de influência para ambas as áreas à luz do conceito de interculturalidade, o qual pressupõe uma interação e enriquecimento mútuos entre diferentes sociedades. Num segundo momento, contemplamos a interface propriamente dita, e apresentamos a tradução como representação cultural do fato noticioso (ZIPSER, 2002), bem como o jornalista como tradutor deste acontecimento. O caráter inovador dessa proposta vincula-se ao modo como tradução e jornalismo se articulam, ampliando a noção de texto para o próprio fato gerador da notícia. Tal conceito difere dos moldes reconhecidamente mais tradicionais e abre uma nova possibilidade de experiência tradutória.

\section{A perspectiva funcional de Christiane Nord}

Em se tratando de estudar a tradução consideramos sempre importante esclarecer o espaço teórico do qual a fala emerge, visto que muitos conceitos são geralmente intercambiáveis e suscitam inúmeras interpretações que, muitas vezes, podem não ser aquelas intencionadas 
pelo autor. No caso de Nord (1997), estamos em território funcionalista, ou seja, partimos "da prioridade da função comunicativa que determinadas estruturas lingüísticas exercem para servir à intenção pragmática do usuário da língua e da análise de estruturas que contribuem para esta função" (WEININGER, 2000, p. 35). Em outras palavras, o funcionalismo vê a linguagem como um meio de interação, uma atividade que detém um propósito comunicativo que, para atingir seu objetivo, faz uso das funções da linguagem tal como Jakobson (1960) e Bühler (1934) as desenvolvem: referencial, emotiva, conativa, fática, metalingüística e poética, cada uma diretamente ligada a um dos fatores intervenientes no ato da comunicação.

Desse ponto de vista, Nord conceitua o ato tradutório como um processo de comunicação intercultural, o qual envolve três agentes principais: o Emissor (autor, iniciador), o Tradutor (mediador cultural) e o Receptor (leitor-final). A ação conjunta desses agentes determina que: i) todo texto (seja ele o original ou o texto traduzido) está inserido em uma situação comunicativa, isto é, o texto é gerado a partir de uma situação concreta, neste caso, o fato noticioso; ii) toda produção textual, salvo raras exceções, é essencialmente prospectiva, ou seja, voltada a um Receptor que traz consigo experiências de outras leituras, perspectivas de vida, de sociedade e de cultura específicas e, iii) todo texto traz uma intenção, uma função (skopos) que, além de ser uma condição determinante da própria produção textual, é concretizada somente quando o leitor-final recebe (lê) o texto,

O fato de a tradução ser um ato-comunicativo-em-situação ${ }^{3}$, voltado a um leitor- final, prospectivo, faz do processo tradutório um ato marcado pelas referências culturais do contexto do qual o leitor-destinatário participa, uma vez que a tradução, segundo Nord, não ocorre somente ao nível do código, mas primordialmente ao nível da cultura ${ }^{4}$ na qual o leitor está inserido. O leitor define, assim, oskopos da tradução e, também, as estratégias, escolhas e decisões do tradutor, neste caso, do jornalista ao longo de todo o processo de escrita. Nesse sentido, compartilhamos com Nord o fato de que os textos devem funcionar culturalmente para o leitor no que diz respeito ao processo de construção de sentidos através da leitura, sobre o qual a autora comenta ${ }^{5}$ :

\footnotetext{
${ }^{3}$ Communicative act-in-situation (NORD, 1991). Isto significa dizer que os textos carregam dimensões históricas e culturais que condicionam o conhecimento, as expectativas, as avaliações bem como o ponto de vista dos agentes envolvidos no ato comunicativo, seja este verbal ou escrito.

${ }^{4}$ Segundo Nord": Language is to be regarded as part of culture (...) and communication is conditioned by the constraints of the situation-in-culture" (NORD, 1997a, p.1).

5 "Las siguientes consideraciones se basan en un concepto funcional de la comunicación. Si es verdad que la traducción es una forma de comunicación intercultural, la traducción funcional procura producir textos que no sólo "funcionen" en la cultura meta, sino que también funcionen de la manera pretendida por el cliente que ha encargado la traducción" (NORD, 2004).
} 


\begin{abstract}
As seguintes considerações se baseiam em um conceito funcional da comunicação. Se é verdade que a tradução é uma forma de comunicação intercultural, a tradução funcional busca produzir textos que não só "funcionem" na cultura-alvo, como também funcionem da maneira pretendida pelo cliente que tenha encomendado a tradução (NORD, 2004).
\end{abstract}

Buscando respeitar a funcionalidade textual, a autora propõe critérios externos e internos ao texto para a análise do contexto de produção do texto original, para só então pensar os fatores a serem considerados numa eventual tradução. Cabe ressaltar, ainda, que o modelo proposto por Nord é aplicável a qualquer estilo de texto (literário, poético, turístico, técnico, científico) não sendo, portanto, idealizado exclusivamente para textos jornalísticos ${ }^{6}$.

Tais critérios partem, a princípio, da análise de um texto-fonte (TF) a fim de que o tradutor possa antecipar pontos em que terá que retrabalhar esse texto com base na cultura-alvo, tornando-o funcional ao leitor-destinatário. Os critérios de análise envolvem: i) fatoresextratextuais (FE) ou a situação comunicativa (moldura histórico-social) de recepção do TF e de produção do texto traduzido (TT): Emissor, Intenção, Receptor, Meio, Lugar, Tempo, Propósito e Função e, ii) fatores-intratextuais (FI) ou os constituintes internos que se articulam para veicular a mensagem: Tema, Conteúdo, Pressuposições, Estruturação, Elementos não-verbais, Léxico, Sintaxe, Elementos supra-segmentais e Efeito do texto.

Temos aqui um ponto de aproximação que configura essa interface de trabalho: o paralelo entre os FE com as perguntas geradoras do lead (ou lide) clássico que resume a matéria para o leitor: quem/o que, fez o que, quando, onde, como, porque/para que. Os FE e os FI são interdependentes e atuam em dinâmica constante; isto significa que qualquer modificação em um desses níveis afeta os outros inevitavelmente. Uma última observação se faz ainda necessária sobre o modelo de Nord: o fato de que textos jornalísticos, nesse sentido, satisfazem uma condição inerente à proposta: são textos autênticos, em contexto de situação real e voltados a um público leitor específico dentro da realidade dos mídia.

\title{
O modelo de Frank Esser
}

O outro vértice da interface contempla o trabalho do jornalista alemão Frank Esser ${ }^{7}$, cuja tese compreende o jornalismo como um 'sistema parcialmente atuante' na sociedade, ou

\footnotetext{
${ }^{6}$ A proposta da autora é a de uma tradução orientada para análise textual, sistematizada mais especificamente para o treinamento de tradutores. Na prática, ainda que muitos destes fatores pareçam óbvios, essa sistematização promove uma reflexão acerca da condução do processo, permitindo ao tradutor conscientizar-se de seus passos e avaliar a qualidade do seu trabalho.

${ }^{7}$ A proposta de Frank Esser resulta ainda inédita no contexto brasileiro, cujas reflexões derivam de sua tese de doutoramento, ainda não traduzida para o português. Seu estudo está presente no trabalho de Zipser (2002).
} 
seja, o jornalismo influencia a partir da prática adotada nas redações, ao mesmo tempo que é influenciado pelo contexto social no qual está inserido e que também representa (ESSER, 1998, p. 478). Essa concepção aponta, a exemplo de Nord, para fatores de influência que afetam a produção textual jornalística e interferem não só na maneira como o público-leitor recebe os textos, mas também na abordagem conferida à notícia.

Esser afirma que "o jornalismo de cada país é marcado por condições sociais, fundamentos históricos e jurídicos, limitações econômicas, bem como por padrões éticos e profissionais de seus agentes" (ESSER, 1998, p. 21). Sua reflexão se fundamenta no conceito de interculturalidade ${ }^{8}$, no sentido de que o jornalismo de cada país possui uma identidade nacional e cultural próprias, refletidas no modo como a imprensa notícia, informa e forma a opinião do leitor. Esses condicionantes são sistematizados no Modelo Pluriestratificado Integrado [ou "Metáfora da Cebola" - Fig.1]. Neste, aspectos sociais, políticos, normativos e subjetivos constituem uma moldura e interagem de forma dinâmica no espaço da prática jornalística, sempre permeados pela ética e específicos para cada contexto cultural. Em outras palavras, o jornalismo americano, inglês, ou o brasileiro são distintos entre si porque possuem estruturas, valores-notícia, profissionais e práticas voltadas aos seus próprios contextos sociais, políticos, econômicos, históricos que atuam de forma dinâmica e intercambiável. Essa proposição questiona a visão consensual do compromisso com a neutralidade, com a isenção que desconsidera o dinamismo da linguagem e os fatores que influenciam o processo de construção de sentido através dos textos.

Do ponto de vista teórico, Esser aproxima-se dos estudos da tradução por sistematizar, assim como Nord, elementos que permitem explorar a forma de atuação do jornalismo em ambiente internacional e, por conseqüência, compreender os mecanismos que conduzem aos diferentes enfoques dados aos acontecimentos quando estes se deslocam internacionalmente.

\footnotetext{
${ }^{8} \mathrm{O}$ conceito de interculturalidade trata, de forma geral, do fenômeno de interação entre culturas diversas, de descentralização e apreciação de diferenças, de modo que se possa caracterizar a singularidade de cada indivíduo, juntamente com o seu contexto cultural (POLCHLOPEK, 2005a).
} 


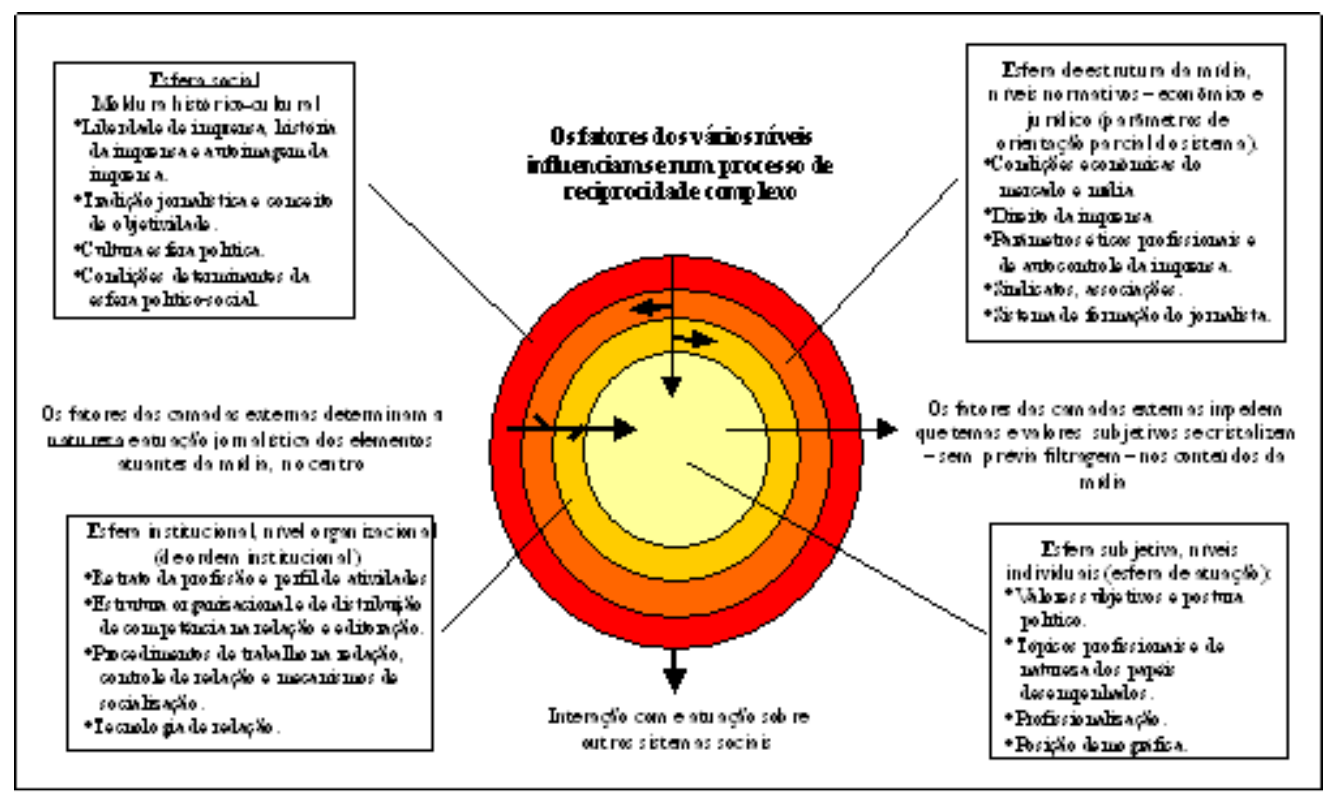

Fig. 1 - Modelo Pluriestratificado Integrado (Esser. 1998 ).

Ambas as sistematizações - de Esser e Nord - vinculam ainda a construção de sentidos à noção de cultura. Tudo isto ocorre porque, quando em contexto estrangeiro, o pesquisador tende a partir dos seus próprios valores, referências ou experiência de vida, para analisar fatos e circunstâncias. Logo, pensar a interculturalidade, conforme proposto por Esser, abre espaço para a compreensão do Outro através da sua ótica e não através de nossos próprios parâmetros, o que poderia implicar em julgamentos precipitados, equivocados ou mesmo glorificações (ESSER ${ }^{9}, 1998$, p. 19). Desta forma, a percepção de marcas culturais (expressões idiomáticas, estruturas lexicais e sintáticas, etc) passa a ser essencial, pois "sob essa perspectiva, as tarefas de tradutores e jornalistas encontram uma base dinâmica: a da autoconsciência cultural para o encontro com o Outro em sua diferença e de volta ao Próprio" (ZIPSER, 2002, p.11).

As variáveis apresentadas pelo Nord e Esser tornam-se, portanto, responsáveis pela existência de uma dinâmica interativa entre produtor textual (jornalista/tradutor) e receptor (leitor-destinatário). Essa não é uma relação sempre isenta de percalços, visto que a presença de variáveis culturais no relato do fato noticioso, em contexto estrangeiro, exige monitoramento constante, por parte do produtor textual ou do jornalista-tradutor, com vistas a manter a comunicação entre TF e TT, ou entre o fato e a reportagem.

\footnotetext{
${ }^{9}$ Eine international vergleichende Studie birgt Gefahren. Als Feldforscher im fremden Land betrachtet man seinen Untersuchungsgegenstand durch die Brille des Ausländers und bewertet das Wahrgenommene nach den Maßstäben seines Heimatslandes. Das kann zu Mißverständnissen, vorschneller Kritik oder Glorifizierung führen (ESSER, 1998, p.19).
} 


\section{A configuração da interface}

Num primeiro momento, uma interface ‘tradução-jornalismo' pode gerar estranheza, visto que seus elementos de aproximação nem sempre são tão facilmente percebidos. Porém cabe aqui uma pergunta para reflexão: os textos que produzimos não são comunicações, não partem também de contextos reais assim como os fatos noticiosos?

A interface tem por princípio questionar a existência de textos ditos neutros e imparciais, além de considerar a linguagem como manifestação cultural, ou seja, um ato vinculado ao seu contexto de produção. Dessa maneira, a linguagem se constitui como produto de um meio social e processo formador de sentidos, ou seja, desconsiderá-la enquanto manifestação cultural equivale ao que se poderia chamar de um primeiro paralelo entre tradução e jornalismo: a transcodificação isenta é para a tradução o que a neutralidade representa para o jornalismo (ZIPSER, 2002, p. 32).

Conforme dito anteriormente, dentro da interface partimos de uma noção ampliada de texto que se desloca para um ponto anterior aquele que não necessariamente um TF, mas um fato gerador (FG), ou fato-fonte, que se constitui no próprio evento noticioso, isto é, o fato que origina a notícia publicada. Essa postura nos permite compreender o ato tradutório como inserido num contexto real de situação comunicativa e de cultura, princípios que constituem a essência do funcionalismo nos estudos da tradução e que compreende o de texto como uma situação comunicativa - o fato - determinada por comportamentos culturais dos indivíduos integrantes dessa situação, nesse caso, o jornalista-tradutor e o(s) leitor(es). Lembramos Mayra Rodrigues Gomes (2000, p. 19) para quem, antes de registrar e informar, "o jornalismo é ele próprio um fato de língua" (grifo nosso), cujo papel ou função na instituição social é organizála discursivamente, ou seja, dar visibilidade a instituições sociais (história, saúde, esportes, política, governo) integrantes desta situação comunicativa, conforme as instâncias sistematizadas por Esser (1998).

Tal realidade se torna ainda mais significativa pelo fato de que as reportagens, assim como as traduções, serem condicionadas à sua condição geográfica, histórica, social, econômica e à hierarquia existente nas redações (editores, redatores, chefes de redação) ou editoras (revisores, agentes, o próprio autor do texto original). Nesse contexto, pressupomos a existência de filtros culturais, isto é, elementos naturais que integram o sistema de comunicação intercultural e que são pautados nos valores culturais da sociedade para a qual o texto se destina, encurtando assim a distância entre o fato ocorrido e aquele veiculado pela imprensa, em especial quando as notícias transitam em ambientes internacionais. Do fato à reportagem, esses filtros 
atuam no processo de construção de sentido dos textos, auxiliando o leitor na compreensão dos acontecimentos.

É importante lembrar que sempre há, nestes casos, um recorte na maneira de abordar o fato considerando-se o leitor-final, as agendas do veículo da imprensa, bem como os critérios de noticiabilidade determinados por diversas instâncias que vão desde o público leitor ao próprio jornalista que se constrói de acordo os contextos sócio-histórico-culturais nos quais desempenha o seu trabalho. "Tal processo nada mais é do que um correlato, no universo da imprensa, das leituras que se fazem de uma realidade, de um fato. Trata-se, enfim, de uma leitura e não da leitura desse mesmo fato" (ZIPSER, 2002, p.3 - grifo nosso).

\section{A Tradução como Representação Cultural}

É precisamente com esta concepção que concretizamos a interface tradução-jornalismo. Ambos os processos, tradutório e jornalístico, sofrem a influência de variáveis externas e internas na sua produção textual, gerando diferentes perspectivas de abordagem para um mesmo evento noticioso, sempre em relação de dependência com o contexto cultural de origem deste fato e aquele para o qual é relatado. Desta maneira, portanto, validamos a abordagem comparativa em ambiente internacional, visto que as perspectivas de enfoque, a situação histórico-social em que a matéria foi produzida, o modo como o texto é organizado para chegar até o leitor-destinatário. Pode-se afirmar, portanto, que o conjunto de características (perfil) do jornalismo de cada país é mais claramente identificável.

Tomando por base este conjunto de variáveis, afirmamos que as diferentes leituras que fazemos acerca de um mesmo fato representam diferentes 'traduções' do mesmo, pois os processos constitutivos da elaboração de uma notícia se aproximam daqueles utilizados para a tradução. Portanto, a tradução jornalística se coloca em termos culturais e não meramente como uma transcodificação lingüística, a exemplo do que comumente se espera da atividade tradutória. Em consequiência, as próprias escolhas de abordagem para o fato já não podem ser consideradas 'neutras'. Sobre isso comentamos:

Dessa forma, o produto final da reportagem estabelece um vínculo com os fatos, que será o resultado do gerenciamento de múltiplas variáveis, ditadas pelas esferas políticas, sociais, econômicas, pela condicionante da história, pela extensão da liberdade de imprensa, pelo teor de formação de seus agentes e, não menos importante, pelo perfil do público ao qual se destina (ZIPSER, 2002, p. 3). 
A percepção do envolvimento de parâmetros culturais durante esse processo de transposição ou 'tradução' de notícias entre fronteiras internacionais estabelece um novo conceito para se pensar a tradução em meio jornalístico: a tradução como representação cultural, oposta à noção de transcodificação isenta, conforme ditada pelos manuais de redação. Assim, se considerarmos que um mesmo fato noticioso pode ser visto e noticiado de formas diferentes nos diversos ambientes culturais, passamos a conceber a tradução em ambiente jornalístico como uma tradução peculiar: vamos além do ambiente do texto e chegamos no fato, no acontecimento. A partir desse nível, a tradução desse fato, desse acontecimento passa a ser noticiado nas diversas culturas e línguas. Tanto o tradutor quanto o jornalista, muitas vezes visto como jornalista-tradutor por escrever em línguas estrangeiras e não somente na sua língua própria, percorrem esse caminho ao encontro do seu leitor ${ }^{10}$. Na verdade, a função de um texto só se concretiza quando este é lido, elaborado por este leitor. No mundo jornalístico, esse mesmo texto representa, na verdade, um produto final ao mesmo tempo vendável e competitivo. Dessa forma, a leitura que fazemos das notícias é, a exemplo da leitura de uma tradução, apenas uma das muitas que um mesmo fato/texto pode receber, de acordo com o contexto cultural para o qual se destina. A isto chamamos deslocamento de enfoque, ou seja, as diferentes abordagens que um mesmo fato noticioso recebe, ao ser transportado de uma língua/cultura para outra. Essas várias leituras fazem com que o enfoque dado ao fato sofra deslocamentos, diferenciações, adequações ao ambiente de recepção.

Assim visto, o jornalista, por sua vez, passa a assumir a postura de 'tradutor' do fato. Tal posicionamento implica numa percepção mais aguçada dos parâmetros culturais envolvidos no relato noticioso, de modo a fazer com que o texto final - a reportagem impressa - funcione culturalmente para o seu público-leitor, ou seja, de modo que o leitor-destinatário possa reconhecer no texto padrões comuns à sua cultura e depreender sentido dele. Isto porque nem sempre o leitor-destinatário é conhecido do jornalista ou mesmo do tradutor, a não ser que este último tenha recebido determinadas instruções sobre o para quem deverá traduzir o texto. No caso do jornalista, na maioria das vezes, só é possível reconhecer o perfil geral do públicoleitor, muito raramente se partilha de detalhes sobre suas preferências de abordagem para o fato.

Esse reconhecimento só é possível em razão de que o jornalista-tradutor compartilha da cultura do Receptor. Tal fato resulta na tentativa (consciente ou não) por parte do jornalistatradutor de aproximar o fato do leitor que está cultural elou geograficamente distante dele.

\footnotetext{
${ }^{10}$ Não se deve aqui pensar num processo de domesticação textual, mas sim de aproximação e funcionalidade, visto que a intenção e o propósito do TF são mantidos na TT (informar sobre o fato ocorrido). Nenhum elemento do texto gerador é apagado, mas sim aproximado do contexto de recepção do leitor na cultura de chegada.
} 
Convém ressaltar que a literatura jornalística normalmente utiliza o termo 'traduzir' para se referir a um relato que represente o fato tal como ele ocorre, de modo a possibilitar sua compreensão pelo maior número possível de leitores. Até o presente, a mesma literatura não associa a idéia de traduzir à necessidade da adequação cultural dos textos jornalísticos aos leitores aos quais se destinam. O exemplo discutido a seguir exemplifica essa concepção.

\section{Marcas culturais e deslocamento de enfoque}

Para exemplificar as sistematizações apresentadas, selecionamos uma reportagem ${ }^{11} \mathrm{da}$ revista alemã Der Spiegel, referente a um fato marcante na história mundial - a queda do muro de Berlim em 1989 e a reportagem publicada, paralelamente, pela revista Veja no mesmo ano.

Ao observarmos o texto de Der Spiegel, revista alemã de circulação ampla, destinada a um público leitor de senso crítico e discernimento apurado, de Novembro de 1989 (n 46, p.18-28), escrito originalmente em alemão e com o título: Eine friedliche Revolution (Uma revolução pacífica), a queda do muro de Berlim, acontecimento que marcou a história alguns dias antes da publicação do artigo, é expressa pelo antagonismo formado por Revolution (revolução) de um lado, e friedliche (pacífica), de outro. Esse título reflete todas as expectativas e temores - não só! - da população alemã! Temia-se que, se um dia o Muro de Berlim viesse a cair, isso aconteceria sob batalha sangrenta, de conseqüências assustadoras. Mas aconteceu pacificamente, uma revolução importantíssima, mas pacífica. Esse título, seguido de um texto detalhado, resgata a história de um povo e relata que esse mesmo povo participou decisiva e pacificamente da condução dos fatos que levaram à queda do muro.

Já o texto da Veja, também de Novembro de 1989 (nº 46, p.130-140), escrito originalmente em português, ancora seu título na história do Brasil - Já raiou a liberdade - e apresenta o mesmo fato noticioso prometendo ao leitor, já no subtítulo, "uma nova era de surpresas". Ao fazer uso de parte de uma estrofe do Hino Nacional da Independência do Brasil, o texto de Veja traz uma analogia que se confirma ao longo da leitura. Tal procedimento cria de início, um ambiente propício para que o leitor brasileiro perceba a dimensão desse fato noticioso para os alemães.

Assim procedendo, o jornalista-tradutor desenvolve uma estratégia de produção textual de adequação ao seu público-leitor definida, na interface apresentada, como a representação cultural do fato noticioso. Trata-se do mesmo fato - a queda do muro de

\footnotetext{
${ }^{11}$ Por razões de adequação às normas deste artigo, não reproduzimos as reportagens analisadas integralmente.
} 
Berlim - apresentado ao leitor através de perspectivas distintas, porém adequadas à sua cultura, segundo os fatores de influência sistematizados por Nord e Esser. Trata-se, portanto, do mesmo tema sim, mas relatado sob perspectivas culturais, não somente em idiomas distintos.

\title{
Considerações finais
}

A presença de marcas culturais nos textos confirma a tentativa, consciente ou não, por parte do jornalista-tradutor de aproximar o fato de um leitor que se encontra cultural elou geograficamente distante deste fato. Estas referências, com a mesma naturalidade com que atravessam fronteiras definem valores inerentes aos mais diversos contextos culturais e asseguram o processo de comunicação. Tal fato é o que legitima a tarefa do tradutor: $o$ motivo da integração entre as diversas línguas (Polchlopek, 2005, grifo nosso). A presença destas marcas culturais nos textos, embora nem sempre facilmente visíveis, é uma constante que vai além de estabelecer a ponte entre o conhecimento prévio do leitor-destinatário e o novo, adquirido através da leitura. Essa realidade confirma o que diz Nord ${ }^{12}$ (2004)sobre o fato de que a função textual somente se completa quando o texto é, de fato, lido:

\begin{abstract}
A função ou funcionalidade não é uma qualidade inerente aos textos. É o receptor do texto quem lhe atribui uma função no mesmo instante e na situação na qual o recebe. O produtor de um texto seja o autor ou o tradutor (...) precisa da cooperação do receptor que, por sua vez, se deixa guiar pelos indicadores funcionais que encontra tanto na situação comunicativa como no próprio texto.
\end{abstract}

Essas escolhas, bem como a própria seleção do que fará parte das reportagens, do que e como será relatado, corroboram o que discutimos no início deste artigo: os princípios que regem o jornalismo (neutralidade, objetividade) sobrevivem à margem da ética dos seus profissionais, pois não tem o domínio na prática em si. Para os pesquisadores jornalistas, esta afirmação certamente poderia causar um terremoto, visto que, estes são conceitos arraigados e transmitidos nos cursos de jornalismo como uma via de mão única e que não permite outros caminhos. Da mesma forma, para os pesquisadores voltados à tradução, em especial na sua acepção mais clássica - TF ® TT - o conceito de tradução cultural pode assumir contornos do que se chamaria uma "metáfora de tradução", ou seja, a tradução jornalística não seria de fato uma tradução, apenas lembraria uma. Isto, no entanto, não se verifica conforme os exemplos discutidos, e outros tantos, que podem ser analisados além dos limites deste artigo. Lembramos

\footnotetext{
12 "La función o funcionalidad no es una cualidad inherente a los textos. Es el receptor de un texto quien le atribuye una función en el mismo instante y en la situación en la que lo recibe. El redactor de un texto, sea autor o traductor (...) necesita la cooperación del receptor, quien, a su vez, se deja guiar por los indicadores funcionales que encuentra tanto en la situación comunicativa como en el mismo texto" (NORD, 2004).
} 
Lya Wyler (2003, p. 36) ao descrever o primeiro ato de tradução da nossa história partindo justamente de um FG: a carta de Pero Vaz de Caminha ao rei de Portugal na qual relata a chegada à nova terra, os habitantes, os atos de índios e portugueses. Se houvesse a possibilidade de termos acesso a algum registro feito pelos índios, certamente teríamos o mesmo fato/evento descrito sob uma outra ótica bastante peculiar, provavelmente expondo o estranhamento aos costumes e modos portugueses.

Enquanto leitores de textos jornalísticos estamos diariamente, em contato com leituras diversas acerca dos mesmos fatos sem, no entanto, nos darmos conta disto. Como conseqüência, somos levados a acreditar no que lemos como a única leitura possível das notícias, quando não o é. Nesse sentido e, ressaltamos, no âmbito do jornalismo, a tradução cultural adquire visibilidade e materialidade através da interface apresentada, sendo pertinente enquanto campo de pesquisa. Acreditamos, nesse sentido, que o perfil de um pesquisador seja o de instigar pensamentos diferentes e estar aberto a novas possibilidades, o que é representativo da nossa proposta: pensar jornalismo e tradução sob perspectivas diferentes, mas que se complementam e se enriquecem entre si.

\section{Referências}

ESSER, Frank. Die Kräfte hinter den Schlagzeilen - Englischer und deutscher Journalismus im Vergleich. München/Freiburg, Verlag Karl Arber, 1998.

FRANZON, Erica. Os valores-notícia em telejornais. Monografia apresentada ao Programa de Pós-graduação em Jornalismo e Mídia da Universidade Federal de Santa Catarina, 2004.

GOMES, Mayra Rodrigues. Jornalismo e Ciências da Linguagem. São Paulo, Hacker Editores, Edusp, 2000.

MEDINA, Cremilda. Notícia: um produto à venda. São Paulo, Summus, $2^{\mathrm{a}}$ ed., 1988.

NORD, Christiane. Text Analysis in Translation. Amsterdan, Atlanta, GA, Rodopi. Tradução de Christiane Nord e Penelope Sparrow, 1991.

\section{Functionalist Approaches Explained.}

Jerome Publishing, Manchester, UK, 1997.

Comunicarse Funcionalmente En Dos Lenguas. In: Léxico Especializado y

Comunicación Interlingüística. Edited by FABER, Pamela; JIMÉNEZ, Catalina \& WORJAK, Berd.Stica, Granada: Granada Lingüística, 2004, p. 285-296

POLCHLOPEK, Silvana. A Tradução de Textos Jornalísticos - Marcas Culturais Aproximando Fronteiras. In: Comunicação apresentada na XIII Jornadas de Jovens Pesquisadores do Grupo Montevideo, Tucumán, Argentina, 2005. 
A Interface Tradução-Jornalismo: um estudo de condicionantes culturais e verbos auxiliares modais em textos comparáveis das revistas Veja e Time. Dissertação (mestrado em estudos da tradução) - Departamento de Comunicação e Expressão da Universidade Federal de Santa Catarina, UFSC, 2005a.

TRAQUINA, Nelson. O estudo do Jornalismo no séc. XX. Editora Unisinos, RS, 2001 ZIPSER, Meta Elisabeth. Do fato a reportagem: as diferenças de enfoque e a tradução como representação cultural. Tese (doutorado em língua e literatura alemã)- Departamentoo de Letras Modernas da Faculdade de Filosofia, Letras e Ciências Humanas da Universidade de São Paulo, USP, 2002.

ZIPSER, Meta Elisabeth e POLCHLOPEK, Silvana A. Introdução aos Estudos da Tradução. Curso de Licenciatura de Letras Espanhol na Modalidade a Distância. Florianópolis, Editora da UFSC, Florianópolis, 2008.

\section{Periódicos}

Revista Veja, no 46, (Novembro de 1989), Editora Abril, São Paulo.

Revista Der Spiegel, no 46 (Novembro de 1989), Spiegel-Verlag Rudolf Augstein GMBHm\&CO.KG. Hamburgo. 